\title{
Cardiac Muscle Contraction
}

National Cancer Institute

\section{Source}

National Cancer Institute. Cardiac Muscle Contraction. NCI Thesaurus. Code C30095.

Driven primarily by voltage-gated $\mathrm{Ca}+2$ action potentials orig inating in sinoatrial pacemaker cells, Cardiac Muscle Contraction involves shortening of the gap junction-linked nonsyncytial striated heart myocytes in the atrial and ventricular chambers that forces movement of the blood through the circulatory system. 